\title{
Fitzroy Sky
}

\section{Chloe Rose}

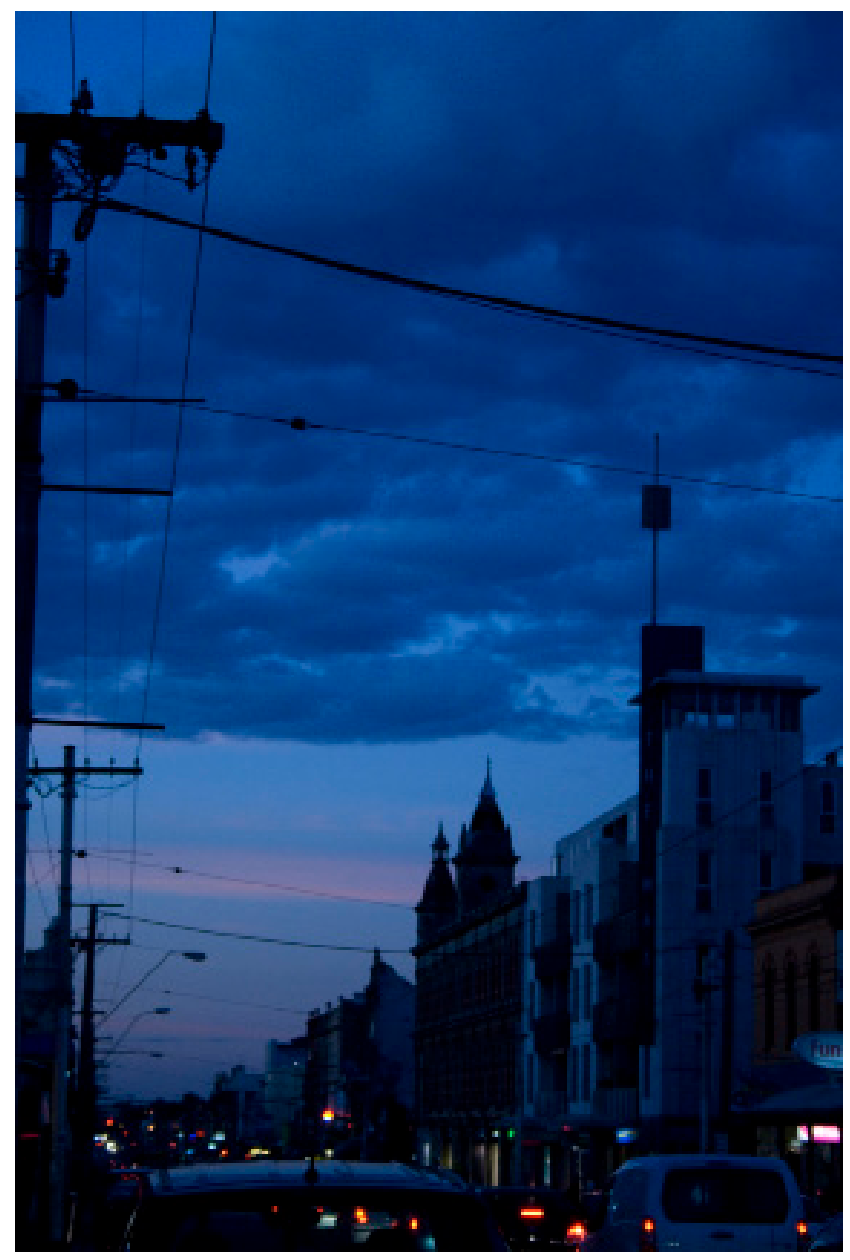

\begin{tabular}{l|l} 
Offset no. 11 & 83
\end{tabular} 